\title{
WEED SUPRESSION BY SMOTHER CROPS AND SELECTIVE HERBICIDES
}

\author{
Francisco José Severino ${ }^{1}$; Pedro Jacob Christoffoleti ${ }^{2 *}$ \\ ${ }^{I}$ USP/ESALQ - Programa de Pós-Graduação em Fitotecnia. \\ ${ }^{2}$ USP/ESALQ - Depto. de Produção Vegetal, C.P. 09 - 13418-900 - Piracicaba, SP - Brasil. \\ *Corresponding author <pjchrist@esalq.usp.br>
}

\begin{abstract}
Using a smother crop is thought to suppress weed density and to add other beneficial effects in sustainable agricultural systems. Weed suppression ought to be considered an essential component of integrated weed management. However, very little is known about the effects of green manure plants on weeds. This study evaluated the influence of three green manure species on weed suppression and selectivity of herbicides. A field experiment was designed to determine the effect of the green manure species Crotalaria juncea, Arachis pintoi and pigeon pea on the weeds Brachiaria decumbens, guineagrass and hairy beggarticks, and on the natural weed infestation in the inter rows area of an avocado orchard. The weed species were suppressed differently by each green manure species. Soil samples collected from the field experiment presented a residual effect, of at least $30 \mathrm{~d}$, in suppressing weed seed bank recruitment; this residual effect was caused by the residues of the green manure present in the soil. When the green manure was incorporated into the top $5 \mathrm{~cm}$ of soil or left on the surface, in a greenhouse experiment, the emergence of weed seeds was significantly inhibited, depending on the species, and on the amount and depth of green manure incorporation. Greenhouse experiments indicate that pre-emergence herbicides cause lower phytotoxicity than post-emergence Arachis pintoi. Smother crops using green manure species, when well established in an area, provide additional weed control to the cropping system and are effective and valuable tools in integrated weed management.

Key words: integrated weed management, seed bank dynamics, phytotoxicity
\end{abstract}

\section{SUPRESSÃO DE PLANTAS DANINHAS POR ADUBOS VERDES E HERBICIDAS SELETIVOS}

\begin{abstract}
RESUMO: A utilização de adubos verdes para supressão de plantas daninhas pode fazer parte do seu manejo integrado nos agroecossistemas. Com o objetivo de avaliar os efeitos supressivos dos adubos verdes Arachis pintoi, Crotalaria juncea L. Cajanus cajan L. Millsp sobre a infestação das plantas daninhas Brachiaria decumbens Stapf., Panicum maximum Jacq., Bidens pilosa L. e infestação natural da área, bem como a seletividade de herbicidas ao Arachis pintoi, submetido a aplicações em pré e pós-emergência, foram instalados quatro experimentos, sendo um em condições de campo e três em casa-de-vegetação, em Piracicaba-SP. Os delineamentos experimentais utilizados foram de blocos casualisados, sendo que o experimento de campo foi instalado em parcelas subdivididas e os de casa-de-vegetação em esquema fatorial. Os parâmetros foram contagem da infestação de plantas daninhas por vaso e ou por $\mathrm{m}^{2}$, produção de biomassa seca das plantas daninhas e das leguminosas, bem como para o Arachis pintoi a produção de biomassa seca e de fitotoxicidade quando submetido a aplicações de herbicidas em pré e pós-emergência. A utilização de adubos verdes contribuiu na redução de populações das plantas daninhas testadas, auxiliando no seu manejo integrado, sendo que as infestações foram suprimidas diferentemente pelos adubos verdes. As aplicações de herbicidas pré-emergentes causaram menor fitotoxicidade e menor redução na produção de biomassa seca do Arachis pintoi do que os aplicados em pós-emergência. Assim, alguns destes herbicidas podem ser utilizados tanto para o controle do crescimento do adubo verde quanto para o controle de plantas daninhas, principalmente no estabelecimento inicial do Arachis pintoi.
\end{abstract}

Palavras-chave: manejo integrado, dinâmica do banco de sementes, fitotoxicidade

\section{INTRODUCTION}

A well-established, living green manure crop can potentially inhibit the germination and establishment of weeds more effectively than desiccated cover crop residues or areas with natural plant residues (Teasdale, 1998). Additional positive benefits to physical and chemical soil properties are gained if the cover crop is a legume. Light transmittance and soil temperature amplitude are reduced more by living than by desiccated mulches. In addition, seedlings that emerge successfully are at a competitive disadvantage with established smother crops. Direct competition for essential growth resources is the main form of weed suppression by any smother crop, which may be 
perennial or annual. Perennials eliminate the need for annual seeding and associated seedbed preparation, also reducing soil erosion.

Native to the central region of Brazil, A. pintoi, a perennial legume was studied in other countries, and only lately has became important for Brazilian agriculture. It has been used in citrus orchards in Florida and Costa Rica (Kiss, 1997), and in Brazil, a series of experiments began in 1995, showing the feasibility of its use in fruit crops of the São Paulo State. A. pintoi has been used as perennial green manure and smother crop because of nitrogen fixation, reduction of soil erosion, and contribution to the suppression of weeds, pathogens, insects, and nematodes (Coleman, 1995). The species prostrate growth habit does not interfere with the normal cultural practices of citrus growers. Studies conducted in Planaltina, in the Cerrados Savannah of Brazil, with A. pintoi as a permanent smother legume crop for corn (Zea mays L.) have shown weed suppression, resulting in a good corn grain yield (Ayarza et al., 1998). In Hawaii, A. pintoi used as a permanent smother crop in a palm tree plantation suppressed weed density significantly, and formed dense living mulch on the soil (Clement \& DeFrank, 1998). These studies show the great potential of using A. pintoi as an integrated weed and for soil management.

Research carried out with annual legume smother crops (Fernandes et al., 1999) has shown that Crotalaria breviflora, Crotalaria spectabilis and pigeon pea reduce weed density, especially in plots with $C$. spectabilis and C. breviflora. In the state of Paraná-Brazil, research with annual legume smother crops, including pigeon pea, as a companion crop to corn, resulted in enough weed control, so that no other weed management practice was necessary. The degree of weed density reduction was a function of the used legume species (Neto, 1993).

The adoption of legume plants as smother crops as part of normal agricultural practice can benefit sustainable agriculture and be part of an integrated weed management system. However, there is a need for local experimentation to establish the benefits of using certain plant species as smother crop (Coleman, 1995). Although smother crops may have potential for controlling weeds, monocultures rarely exist in nature, and even in a smother crop, weeds may invade and become established (Teasdale, 1998). Wilkinson et al. (1987) reported that weed establishment in a tall fescue (Festuca arundinacea L.) living mulch for corn became a major factor limiting yield, after 3 years. Although, smother crops may be effective tools for controlling weeds, they require management to prevent invasion and establishment of weed species over time (Teasdale, 1998).

The influence of three smother crops on fruit crops, using the legumes Arachis pintoi, Crotalaria juncea and pigeon pea, on the population dynamics of Brachiaria decumbens, guineagrass and hairy beggarticks, and the population of natural weed infestations, and the selectivity of pre and post-emergence herbicides to A. pintoi were studied. The major goal of the research was to provide Brazilian fruit growers with scientific information on how to grow legume smoother crops in an integrated weed management system, to reduce the herbicide use and consequently contribute for agriculture sustainability.

\section{MATERIAL AND METHODS}

\section{Competitive Interactions Between Legumes Smother Crops and Weeds}

Field experiments were conducted in PiracicabaSP-Brazil ( $22^{\circ} 45^{\prime} \mathrm{S} ; 47^{\circ} 38^{\prime} \mathrm{W}$; altitude $560 \mathrm{~m}$ ). The Oxisol had $380 \mathrm{~g} \mathrm{~kg}^{-1}$ clay, $190 \mathrm{~g} \mathrm{~kg}^{-1}$ silt, and $430 \mathrm{~g} \mathrm{~kg}^{-1}$ sand, pH 5.3 and $37 \mathrm{~g} \mathrm{dm}^{-3}$ of organic matter. The average temperature of the coldest day was $17^{\circ} \mathrm{C}$ and of the hottest, $24^{\circ} \mathrm{C}$. The total annual average rainfall of the region (30 years) was $1200 \mathrm{~mm}$. The experiments were installed in the interow of an avocado (Persea americana L.) crop, spaced $10 \times 10 \mathrm{~m}$, in a split plot, completely randomized block design, with four replications. In October 1998, subplots $\left(16 \mathrm{~m}^{2}\right)$ were seeded with $1 \mathrm{~g}$ seed $\mathrm{m}^{-2}$ of $B$. decumbens, guineagrass and hairy beggarticks, respectively, plus a subplot without weeds that had natural level native weed infestation. After seeding the weeds, the plots $\left(54 \mathrm{~m}^{2}\right)$ were row planted with A. pintoi, $C$. juncea and pigeon pea, spaced $0.5 \mathrm{~m}$. In November 1999, the experiment was reinstalled with the same design with the plots and subplots installed in the same sites of the previous year. At this time, however, the $A$. pintoi was not reseeded since it is perennial and was already well established. The other plots and subplots were installed normally. Weed infestation was evaluated 60 days after smother crop planting (DAP) and smother crop biomass yield was taken 120 DAP, both years. Data were analyzed through analysis of variance and the averages compared using the Tukey test. Results of the first year presented the same differences among treatments and subtreatments observed in the second year (data not shown); therefore, only the results of the experiment conducted in 1999, that has cumulative effects of smooth crops from two consecutive years, and after $A$. pintoi became a perennial crop, were analysed.

\section{Effects of the Legume Smother Crops on Soil Seed Bank Recruitment}

With a $4.3 \mathrm{~cm}$-diameter soil core sampler soil samples were collected at the $0-10 \mathrm{~cm}$ depth, in each of the subplots (experiment installed in 1999) described in the previous section (10 sub samples were homogenized, and a final composite sample of $1 \mathrm{~kg}$ was taken). The final soil samples from each subplot were placed on $30 \mathrm{~cm}$ x $20 \mathrm{~cm}$ x $5 \mathrm{~cm}$ plastic trays, in a greenhouse with automatic irrigation system and partial control of temperature 
and relative humidity. Emerged weed plants were counted $30 \mathrm{~d}$ after the beginning of the experiment. The experiment was set in a completely randomized design, factorial scheme, with four replications, using two factors: smother crops (A. pintoi, C. juncea, and pigeon pea), and weeds ( $B$. decumbens, guineagrass, hairy beggarticks and natural standing weed infestation). Data were submitted to Anova and the treatment and sub-treatment means compared by the Tukey test, $(P=0.05)$.

\section{Herbicide Selectivity in Arachis pintoi}

Two greenhouse experiments were made using soil samples from the same area of the field experiment, using $200-\mathrm{cm}^{3}$ plastic pots and 10 seeds of A. pintoi per pot. One experiment was sprayed right after green manure seeding, with pre-emergence $1.35 \mathrm{~kg}$ a.i.ha ${ }^{-1}$ trifluralin, $1.5 \mathrm{~kg}$ a.i.ha ${ }^{-1}$ diuron, $0.6 \mathrm{~kg}$ a.i.ha ${ }^{-1}$ oxyfluorfen, $2.0 \mathrm{~kg}$ a.i. $\mathrm{ha}^{-1}$ atrazine, $2.88 \mathrm{~kg}$ a.i.ha ${ }^{-1}$ metolachlor; a check without herbicide application was maintained. The other experiment consisted of post-emergence application of fluazifop-p-butyl at $0.25 \mathrm{~kg}$ a.i.ha ${ }^{-1}$, MSMA at $1.92 \mathrm{~kg}$ a.i.ha ${ }^{-1}$, glyphosate at $0.40 \mathrm{~kg}$ a.i.ha ${ }^{-1}$, ammonium glufosinate at $0.40 \mathrm{~kg}$ a.i.ha ${ }^{-1}$, sulfosate at $0.96 \mathrm{~kg}$ a.i.ha ${ }^{-1}$, and check plot without herbicide application. In both experiments pots were sprayed in a laboratory herbicide spray chamber at $40 \mathrm{psi}$, with a nozzle tip $11002 \mathrm{E}$ and spray volume of $300 \mathrm{~L} \mathrm{ha}^{-1}$. The experiments consisted of a completely randomized design with four replications. Dry biomass production was evaluated $28 \mathrm{~d}$ after herbicide application for both experiments and phytotoxicity was evaluated 30, 60 and $75 \mathrm{~d}$ after pre-emergence herbicide application and 7, 14, 21 and $28 \mathrm{~d}$ after post-emergence application, using a visual rating, ranging from 1 (no phytotoxicity) to 9 (plant death). Data were submit- ted to Anova and the treatment and sub-treatment means compared by the Tukey test, $(P=0.05)$.

Correlation of Legume Smother Crop Quantity, Incorporation Depth into the Soil and Weed Suppression

Using the field soil in the greenhouse, $200 \mathrm{~cm}^{3}$ plastic pots were arranged in a factorial design of $3 \times 6$ x 3 x 2, with three species of legume smother crops ( $A$. pintoi, $C$. juncea, and pigeon pea); six smother crop quantities expressed as multiples of field dry matter (0X, $0.5 \mathrm{X}, 1 \mathrm{X}, 2 \mathrm{X}, 4 \mathrm{X}$ and $8 \mathrm{X}$ ). The $\mathrm{X}$ for $A$. pintoi was 6.5 ton $\mathrm{ha}^{-1}$, for $C$. juncea 17.6 ton $\mathrm{ha}^{-1}$ and for pigeon pea 14.3 ton $\mathrm{ha}^{-1}$. There were three weeds (B. decumbens, guineagrass, and hairy beggarticks) and two depths of crop incorporation (surface and 0-5 cm deep). The weeds were seeded $2 \mathrm{~cm}$ deep. Green manure was either incorporated into the top $5 \mathrm{~cm}$ of soil or left on the soil surface, according to the species and quantities specified in the treatments. Shoot dry weight biomass of the emerged weeds at 15 DAP was evaluated and analyzed according to polynomial linear, quadratic, and cubic regressions.

\section{RESULTS AND DISCUSSION}

Competitive interactions between legume smother crops and weeds, and effects of the legume smother crops on soil seed bank recruitment

Arachis pintoi suppressed guineagrass, hairy beggarticks and the natural weed infestation; however, it did not affect the density of $B$. decumbens, a very aggressive perennial weed (Table 1a). C. juncea and pigeon pea reduced the density of all weeds in the experiment and the natural infestation (Table 1a). The greatest competitive effect on $A$. pinto $i$ was by the weed $B$. decumbens

Table 1 - Effect of smother crop on weed infestation (a) average weed density, evaluated 60 days after smother crop planting (DAP) in the field; (b) Number of weeds per pot, emerged 30 days after soil was placed in the greenhouse and the effect of smother crop on the seed bank recruitment.

\begin{tabular}{|c|c|c|c|c|}
\hline \multirow[b]{3}{*}{ Smother crop $^{\text {a }}$} & \multicolumn{4}{|c|}{ Weed } \\
\hline & B. decumbens & Guineagrass & H. beggarticks & Natural infestation \\
\hline & \multicolumn{4}{|c|}{ (a) Plants $\mathrm{m}^{-2}$} \\
\hline A. pintoi & 33.5 & 18.8 & 5.6 & 19.6 \\
\hline C. juncea & 3.6 & 4.3 & 3.4 & 5.5 \\
\hline Pigeon pea & 12.4 & 3.6 & 4.3 & 13.8 \\
\hline \multirow[t]{4}{*}{ Check } & 36.3 & 72.2 & 37.3 & 130.4 \\
\hline & \multicolumn{4}{|c|}{$\operatorname{LSD}(0.05)=1.12($ smother crops $)-\operatorname{LSD}(0.05)=1.15($ weeds $)$} \\
\hline & \multicolumn{4}{|c|}{ Weed } \\
\hline & B. decumbens & Guineagrass & H. beggarticks & Natural infestation \\
\hline Smother crop $^{1}$ & \multicolumn{4}{|c|}{ (b) Plants pot ${ }^{-1}$} \\
\hline A. pintoi & 26.1 & 8.0 & 2.6 & 76.6 \\
\hline C. juncea & 1.4 & 1.2 & 1.0 & 39.0 \\
\hline Pigeon pea & 4.5 & 7.1 & 9.4 & 66.8 \\
\hline Check & 7.3 & 13.6 & 29.3 & 153.8 \\
\hline
\end{tabular}

${ }^{a}$ For statistical analysis data were transformed as $\sqrt{x+0.5}$ 
followed by guineagrass, hairy beggarticks and natural weed infestation (Table 2). C. juncea growth was affected by guineagrass and natural weed infestation; however, $B$. decumbens and hairy beggarticks did not reduce the green manure crop through competition. The growth of pigeon pea was affected only by hairy beggarticks and the natural weeds (Table 2).

The conclusions from this experiment are that $C$. juncea is the most effective for weed suppression; $A$. pinto $i$ is effective but only for suppression of some weeds (e.g. hairy beggarticks). The use of green manure may contribute to reduce weed populations, acting as auxiliary tool in integrated weed management (Facelli \& Pickett, 1991, Hartwig, 1989, Enache \& Ilnicki, 1990, White \& Scott, 1991, DeHaan et al., 1994). These results support the conclusion of Tasdale (1998) that smother crops have potential to control weeds in herbicide-free cropping systems. However, to effectively prevent weed establishment and also to have the appropriate phenology to complement resource use by the cash crop, the smother crop must consistently develop an uniform, competitive ground cover. Development of these smother crops represents a challenge to future weed scientists, ecophysiologists, and breeders (Teasdale, 1998), and legume smother crops meet these requirements for use in orchards.

Soil seed bank recruitment of all studied weeds, except $B$. decumbens, was reduced by $A$. pintoi, $C$. juncea and pigeon pea (Table 1b). Legume smother crops had residual effect on the soil seed bank, since recruitment was measured $30 \mathrm{~d}$ after the soil was placed in the greenhouse. Pigeon pea is the most effective green manure for the reduction of seed bank recruitment by $B$. decumbens, hairy beggarticks and natural infestation. Hairy beggarticks was mostly affected by A. pintoi. The general conclusion is that weed seed bank dynamics can be affected by a green manure, even after the smother crop is removed.

Crop rotation with legumes is an efficient cultural practice to control weeds through diversification of the selection pressure by altering the pattern of disturbance of the soil. Crop rotation can reduce seed bank size, because the sequence of crops imposes different models of competition, alelopathic effects, and disturbance, thus re- ducing the selection pressure on specific weeds (Buhler et al., 1997). When rotational cropping systems are designed, smaller seed bank has resulted (Ball \& Miller, 1990, Schreiber, 1992).

\section{Herbicide Selectivity for Arachis pintoi}

Diuron at $1.5 \mathrm{~kg}$ a.i.ha ${ }^{-1}$ was selective for $A$. pintoi and did not affect shoot dry biomass yield; low phytotoxicity was observed (Table 3 ). Trifluralin at $1.35 \mathrm{~kg}$ a.i.ha ${ }^{-1}$, oxyfluorfen at $0.6 \mathrm{~kg}$ a.i. $\mathrm{ha}^{-1}$ and metolachlor at $2.88 \mathrm{~kg}$ a.i.ha ${ }^{-1}$ reduced shoot dry biomass and exhibited visual phytotoxicity during the first two evaluations; the injury would, however, be acceptable. Atrazine at $2.0 \mathrm{~kg}$ a.i.ha ${ }^{-1}$ killed A. pintoi.

Glyphosate at $0.72 \mathrm{~kg}$ a.i.ha ${ }^{-1}$, ammonium glufosinate at $0.40 \mathrm{~kg}$ a.i.ha ${ }^{-1}$ and sulfosate at $0.96 \mathrm{~kg}$ a.i.ha ${ }^{-1}$ sprayed post-emergence were not selective for A. pintoi (Table 3). However, fluazifop-p-butyl at $0.25 \mathrm{~kg}$ a.i.ha ${ }^{-1}$ and MSMA at $1.92 \mathrm{~kg}$ a.i.ha ${ }^{-1}$ did not cause any injury to the green manure, even though some visual symptoms of phytotoxicity were observed up to 75 $\mathrm{d}$ after the application of the herbicide.

Legume smother crops can suppress weed infestation and be an effective tool in integrated weed management. However, some species of green manure are not very competitive during establishment, so weeds can compete with them. Sometimes weed control methods are required during the initial growth and establishment of the legume smother crop (Teasdale, 1998). On the other hand, a living mulch, which is competitive enough to suppress weeds, usually will suppress the crop as well. Several herbicides have been sprayed at sub-lethal rates to control weeds in green manure with the objective of either control or reducing the green manure crops initial growth (Eberlein et al., 1992; Elkins et al., 1983; Hartwig, 1987).

\section{Correlation of Legume Smother Crop Quantity, Incor- poration Depth into the Soil and Weed Suppression}

All three legume smother crops suppressed emergence and biomass of the weeds and the greater the amount of green manure that was incorporated into the soil or left on the soil surface, the higher was the weed suppression (Figures 1a to 1d). The greatest effect was

Table 2 - Effect of smother crop on weed infestation on the average green manure shoot dry weight - 120 days after planting (DAP), in a field experiment.

\begin{tabular}{lccc}
\hline & & Shoot dry weight of smother crop \\
\cline { 2 - 4 } Weed & A. pintoi & C. juncea & Pigeon pea \\
\hline & 83.8 & 675.4 & 354.1 \\
Guineagrass & 149.6 & 411.1 & 341.0 \\
Hairy beggarticks & 185.3 & 672.4 & 196.8 \\
Natural infestation & 143.9 & 603.1 & 255.6 \\
Check & 259.4 & 790.8 & 396.6 \\
\hline
\end{tabular}

${ }^{1}$ For statistical analysis data were transformed as $\sqrt{x+0.5}$ 
Table 3 - Shoot dry biomass and phytotoxicity of A. pintoi sprayed with pre and post-emergence herbicides in the greenhouse.

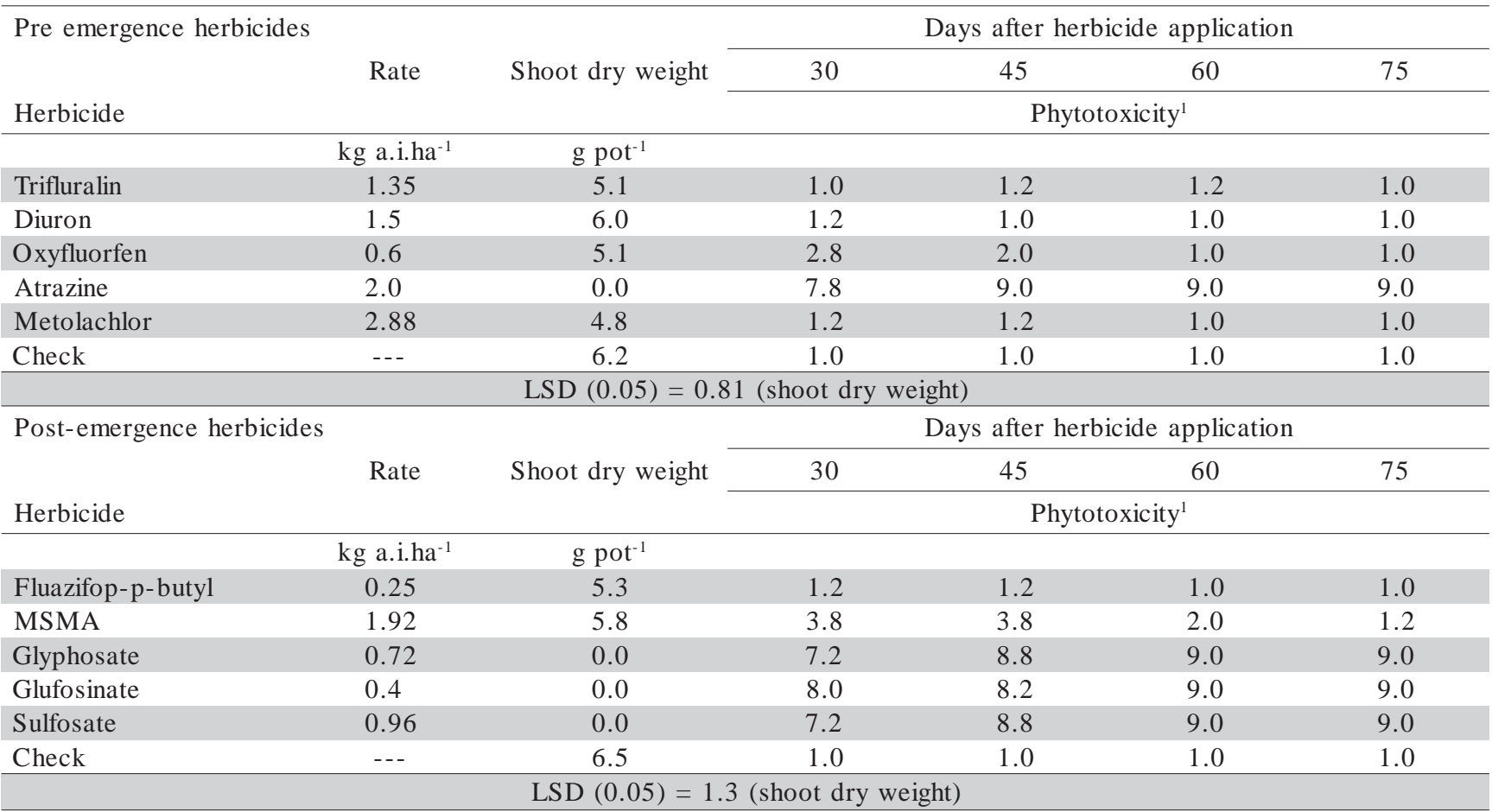

${ }^{1}$ Rated from 1 to 9 , where 1 = no visual phytotoxicity effects observed and $9=$ plant kill.

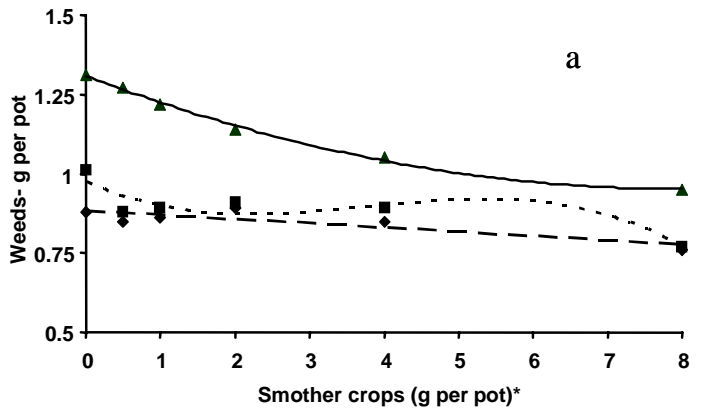

- B. decumbens $-\mathrm{y}=-0.0134 . \mathrm{x}+0.8829 \quad \mathrm{R}^{2}=0.7558$

- P. maximum - $\mathrm{y}=-0.003 . \mathrm{x}^{3}+0.034 . \mathrm{x}^{2}-0.1071 . \mathrm{x} .0 .9758 \quad \mathrm{R}^{2}=0.8214$

- B. pilosa - $\mathrm{y}=0.0056 . \mathrm{x}^{2}-0.0889 \mathrm{x}+1.3075 \quad \mathrm{R}^{2}=0.997$

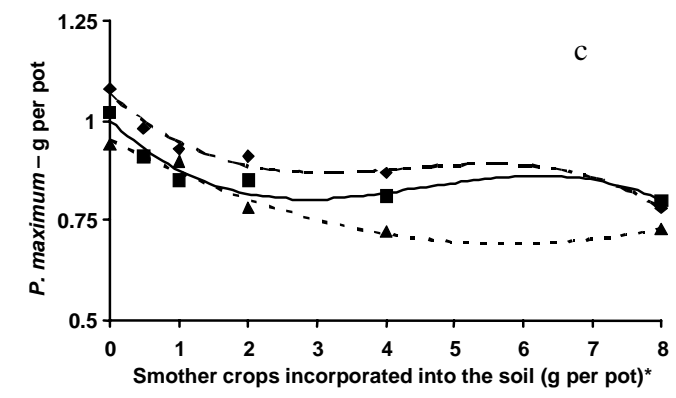

- A. pintoi $-\mathrm{y}=-0.003 \cdot \mathrm{x}^{3}+0.0389 \cdot \mathrm{x}^{2}-0.1545 \cdot \mathrm{x}+1.0646 \quad \mathrm{R}^{2}=0.9739$

- C. juncea $-\mathrm{y}=-0.003 \cdot \mathrm{x}^{3}+0.0413 \cdot \mathrm{x}^{2}-0.162 \cdot \mathrm{x}+0.9998 \quad \mathrm{R}^{2}=0.9213$

- C. cajan $-\mathrm{y}=-0.0078 . \mathrm{x}^{2}-0.0902 \cdot \mathrm{x}+0.9521 \quad \mathrm{R}^{2}=0.9666$

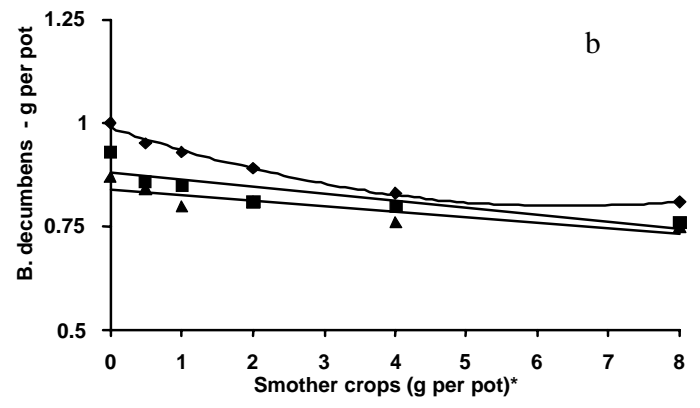

- Arachis pintoi $-\mathrm{y}=0.0046 . \mathrm{x}^{2}-0.059 . \mathrm{x}+0.9888 \quad \mathrm{R}^{2}=0.9898$

- Crotalaria juncea - $\mathrm{y}=-0.0169 . \mathrm{x}+0.8786 \quad \mathrm{R}^{2}=0.7412$

- Cajanus cajan $-\mathrm{y}=-0.0132 \mathrm{x}+0.8391 \quad \mathrm{R}^{2}=0.7485$

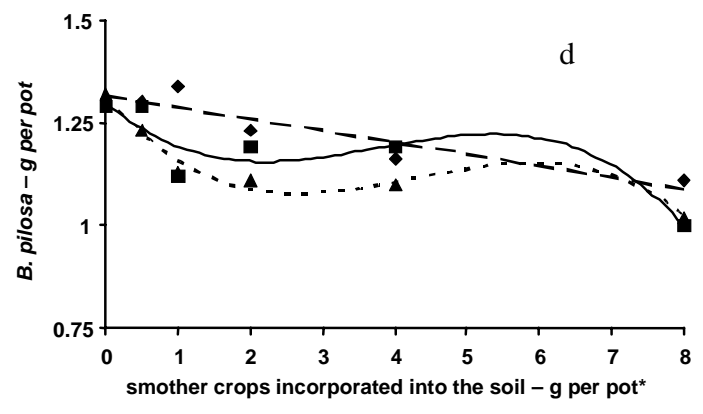

- A. pintoi $-\mathrm{y}=-0.0282 . \mathrm{x}+1.3146 \quad \mathrm{R}^{2}=0.8597$

- C. juncea - $\mathrm{y}=-0.0043 \cdot \mathrm{x}^{3}+0.0487 \cdot \mathrm{x}^{2}-0.1518 . \mathrm{x}+1.2998 \quad \mathrm{R}^{2}=0.8433$

- C. cajan - $\mathrm{y}=-0.0044 . \mathrm{x}^{3}+0.0567 . \mathrm{x}^{2}-0.2087 . \mathrm{x}+1.3145 \quad \mathrm{R}^{2}=0.9764$

Figure 1 - (a) Shoot dry weight of weeds per pot, according to smother crop quantity left on the soil surface. Data for the three species of smother crops (A. pintoi, $C$. juncea and pigeon pea) were combined because there was no significant interaction; $b, c$ e d. Shoot dry weight of guineagrass (b), B. decumbens (c), beggarticks (d) per pot, as a function of crop incorporation into soil.

Note* - The values expressed on the $\mathrm{x}$ axis corresponds to the weight of smother crops applied on the surface of the pot expressed as a multiple of the field dry matter yield (0X, 0.5X, 1X, 2X, $4 \mathrm{X}$ and $8 \mathrm{X})$; the $\mathrm{X}$ for A. pintoi was 6.5 ton ha ${ }^{-1}$, for C. juncea 17.6 ton $\mathrm{ha}^{-1}$ and for pigeon pea 14.3 ton $\mathrm{ha}^{-1}$.

Sci. Agric. (Piracicaba, Braz.), v.61, n.1, p.21-26, Jan./Fev. 2004 
on hairy beggarticks. When the smother crop shoot biomass was left on the soil surface, there was no difference in the effect among the legumes. Figure 1a shows the average value for the weed biomass yield as a function of the average of the three legume species. Different effects were observed when smother crops were incorporated into the soil. Results are shown by species in Figures $1 \mathrm{~b}$ to 1d. Guineagrass was highly suppressed by the three green manure crops. However, the greatest effect was caused by pigeon pea, especially with the higher quantities incorporated into soil. Very little difference was observed in the suppressive effect of the smother crops on $B$. decumbens (Figure 1c), but there was high variability in suppression of hairy beggarticks (Table 3 ). The least effect was observed for the suppression by A. pintoi.

Even though green manure smother crops have been studied intensively, few results focus on the establishment of a relationship with weed suppression (Christoffoleti, 1988). Several important weeds do not establish well if crop rotation is practiced (Walker \& Buchanan, 1982). A negative linear correlation of shoot dry biomass weight of weeds $\mathrm{m}^{-2}$, as a function of shoot dry weight of different species of cover crops biomass increase, after 85 days of incorporation of the crop into the soil, was reported by Almeida \& Rodrigues (1985) in areas were no-till systems have been practiced. The overall conclusion of the research reported here confirm weed suppression by smoother crops, suggesting, therefore, that these crops could be part of integrated weed management systems in Brazil.

\section{ACKNOWLEDGMENTS}

To CAPES for financial support.

\section{REFERENCES}

ALMEIDA, F.S.; RODRIGUES, B.N. Guia de herbicidas: recomendações para uso em plantio direto e convencional. Londrina: IAPAR, 1985. 468p.

AYARZA, M.A.; VILELA, L; PIZARRO, E.A. Estratégias de cultivo de milho (Zea mays) sobre cobertura permanente de Arachis pintoi. Planaltina: EMBRAPA, v.20, p.28-30, 1998.

BALL, D.A.; MILLER, S.D. Weed seed population response to tillage, and herbicide use in three irrigated cropping sequence. Weed Science, v.38, p.511-517, 1990.

BUHLER, D.D.; HARTZLER, R.G.; FORCELLA, F. Implications of weed seedbank dynamics to weed management. Weed Science, v.45, p.329336, 1997.
CHRISTOFFOLETI, P.J. Controle de Brachiaria decumbens Stapf e de Cyperus rotundus $\mathrm{L}$. em área de cana-de-açúcar (Saccharum $\mathrm{spp}$ ) através da técnica de rotação com amendoim (Arachis hypogaea L.) integrada ao uso de herbicidas. Piracicaba: USP/ESALQ, 1988. 117p. (Dissertação - Mestrado)

CLEMENT, C.R.; DEFRANK, J. The use of ground covers during the establishment of heart-of-palm plantations in Hawaii. HortScience, v.33, p.814-815, 1998.

COLEMAN, R.G. Perennial peanuts - potential looms larger in citrus. Citrus Industry, v.45, p.43-44, 1995.

DEHAAN, R.L.; WYSE, D.L.; EHLKE, N.J. Simulation of spring-seeded smother plants for weed control in corn. Weed Science, v.42, p.35-43, 1994.

EBERLEIN, C.V.; SHEAFFER, C.C.; OLIVEIRA, V.F. Corn growth and yield in an alfalfa living mulch system. Journal of Production Agriculture, v.5, p.332-339, 1992.

ELKINS, D.; FREDERKING, D.; MARASHI, R. Living mulch for no-tillage corn and soybeans. Journal of Soil and Water, v.38, p.431-433, 1983.

ENACHE, A.J.; ILNICKI, R.D. Weed control by subterranean clover used as living mulch. Weed Technology, v.4, p.534-538, 1990.

FACELLI, J.M.; PICKETT, S.T.A. Plant litter: its dynamics and effects on plant community structure. Botanical Review, v.57, p.1-32, 1991.

FERNANDES, M. F.; BARRETO, A.C.; EMIDIO FILHO, J. Fitomassa de adubos verdes e controle de plantas daninhas em diferentes densidades populacionais de leguminosas. Pesquisa Agropecuária Brasileira, v.34, p.1593-1600, 1999.

HARTWIG, N.L. Cropping practices using crownvetch in conservation tillage. In: POWER, J.F. (Ed.) The role of legumes in conservation tillage systems. Ankeny: Soil Conservation Society of America, 1987. p.109-110.

HARTWIG, N.L. Influence of crownvetch living mulch on dandelion invasion in corn. Northeast Weed Science Society, v.33, p.25-28, 1989.

KISS, J. Cobertura viva. Revista Globo Rural, v.37, p.9-11, 1997.

NETO, F.S. Controle de plantas daninhas através de coberturas verdes consorciadas com milho. Pesquisa Agropecuária Brasileira, v.28, p.1165-1171, 1993.

SCHREIBER, M.M. Influence of tillage, crop rotation, and weed management on giant foxtail (Setaria faberi) population dynamics and corn yield. Weed Science, v.40, p.645-653, 1992.

TEASDALE, J.R. Cover crops, smother plants, and weed management. In: HATFIELD J.L. (Ed.) Integrated weed and soil management. Boca Raton: Sleeping Bear Press, 1998. p.247-270.

WALKER, R.H.; BUCHNAN, G.A. Crop manipulation in integrated weed management systems. Weed Science, v.30, p.17-24, 1982.

WHITE, J.G.; SCOTT, T.W. Effects of perennial forage-legume living mulches on no-till winter wheat and rye. Field Crops Research, v.28, p.135-148, 1991.

WILKINSON, S.R.; DEVINE, M.; BELESKY, J.W. No-tillage intercropped corn production in tall fescue sod as affected by sod control and nitrogen fertilization. Agronomy Journal, v.79, p.685-690, 1987.

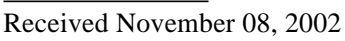

Accepted October 23, 2003 